\title{
Exploring Depictions of Bedouins in Travels in Arabia Deserta by Charles Doughty
}

\author{
Alaa Ahmed Alzahrani* \\ King Saud University, Riyadh 12641, Saudi Arabia \\ Corresponding Author: Alaa Ahmed Alzahrani, E-mail: alaa-zahrani@hotmail.com
}

\section{ARTICLE INFO}

Article history

Received: July 05, 2018

Accepted: September 01, 2018

Published: December 01, 2018

Volume: 7 Issue: 7

Advance access: October 2018

Special Issue on Language \&

Literature

Conflicts of interest: None

Funding: None

\begin{abstract}
The discourse of Orientalism has often been explored from a Critical Discourse Analysis (CDA) perspective in fiction works and news media published in the $20^{\text {th }}$ and $21^{\text {st }}$ centuries. What remains a largely unexplored area is Oriental views in non-fiction Western writings of the $19^{\text {th }}$ century. One of the key books describing the people of Arabia from this era is Charles Doughty's (1888) Travels in Arabia Deserta. For this reason, this study analyzed one chapter from this book to explore Doughty's representation of the Arabian Peninsula Bedouins. By drawing on CDA and the Appraisal framework, this study identified evaluative lexical items used by Doughty to describe the Bedouins and related these lexical choices to three Oriental themes identified in the literature: (1) Oriental inferiority, (2) Oriental barbarity, and (3) Oriental untrustworthiness. An examination of the Oriental themes in Doughty's book highlights two characteristics of the discourse of Orientalism. One is the underlying cultural superiority of the West and the other is the interdependence of texts describing the people of Arabia. As such, this paper supports the idea that what is encompassed by the label "discourse of Orientalism" can include even seemingly neutral descriptions of people of Arabia, and that existing representations of Arabs are a product of an accumulated body of work rather than from one specific text.
\end{abstract}

Key words: Orientalism, Orientalist Stereotypes, Critical Discourse Analysis, Appraisal Framework, European Discourse, Travel Writing, $19^{\text {Th }}$ Century Literature, Arabia

\section{INTRODUCTION}

The term Orientalism refers to Western-constructed images of the Arab world. This concept was theorized by Edward Said (1978), who traced its roots back to the European discourse of the late $18^{\text {th }}$ century. The importance of identifying the early beginnings of this European discourse is evident in the repeated calls to analyze texts produced in earlier historical periods (Burke \& Prochaska, 2008; Dabashi, 2009; Varisco, 2017). The central role of Oriental travelers in shaping representations of the Arabian Peninsula Arabs and sustaining them through discourse is widely recognized (Jarmakani, 2008; Macfie, 2009; MacKenzie, 1995). This is evident in the role played by $19^{\text {th }}$-century British travelers in perpetuating narratives of the $18^{\text {th }}$ century and further legitimizing the Orientalist discourse (Long, 2014). This twoway relation between Orientalism and discourse has led to an interest in employing Critical Discourse Analysis (CDA) to investigate Orientalism (e.g., Al-Malik, 2014; Alghamdi, 2015; Faimau, 2013; Izadi \& Saghaye-Biria, 2007; Poorebrahim \& Reza Zarei, 2013; Ventura, 2017). However, the scope of these studies has been confined to the critical analysis of fiction works and news media published in the $20^{\text {th }}$ or $21^{\text {st }}$ centuries. A further limitation of this body of work is that it has attempted to explain the persistence of negative views toward the Arabian Peninsula Arabs rather than tracing the early beginnings of such views. This study was conducted in response to the dearth of literature using CDA to study the representation of the Arabian Peninsula Arabs in non-fiction Western writings of the $19^{\text {th }}$ century, the likely importance of these early writings in shaping certain representations, and the scarcity of studies using the Appraisal framework to explore such representations. As such, this study investigates the representation of the Arabian Peninsula Arabs in the work of a British traveler in the $19^{\text {th }}$ century. Specifically, this study seeks to critically analyze the evaluative items used to describe the customs of the Bedouins in Charles Doughty>s (1888) Travels in Arabia Deserta.

The significance of this study thus stems from exploring one of the early representations of the Arabian Peninsula Bedouins in a travel writing book (Cocking, 2007). This exploration might show that representations of the Arabian Peninsula Bedouins as the Oriental "other" are maintained through a travel book written by an objective author (e.g., Nash, 2011) with a lack of colonial interests. This study aims to examine the use of lexical items and eventually trace Oriental themes in the depiction of Bedouins' customs in Travels in Arabia Deserta by drawing on CDA and the Appraisal framework in its analysis. To unpack the 
Orientalist discourse in Doughty's (1888) Travels in Arabia Deserta, the present study addresses the following two research questions:

1. How did Doughty use lexical items to describe the Bedouins' customs in his book?

2. How is the linguistic description related to the following Oriental themes: (1) Oriental inferiority, (2) Oriental barbarity, and (3) Oriental untrustworthiness?

\section{CONTEXT OF THE ANALYSIS}

This section considers the author's background and the genre of the book to better understand the discourse of Travels in Arabia Deserta. Starting with the author, Charles Montagu Doughty was a British traveler and writer born in 1843 (Nash, 2011). He was once described as a "lone, near martyred traveler" (Long, 2014, p. 50). He is one of the most highly regarded early Western visitors to Arabia. His book Travels in Arabia Deserta is a testament to such a status (Encyclopaedia Britannica, 2016). Doughty's journey as described in Travels in Arabia Deserta started in November 1876 when the writer took on the Arabic name "Khalil" to enter Arabia without concealing his Christian faith. This journey to Arabia was motivated by Doughty's interests in the region's archeology (Sullivan, 1969). This is a plausible explanation given his academic background in science and lack of interest in politics (Youngs, 2006).

To better understand the language used in this book, general information about the author should be provided and the genre of the book identified. The genre of this book is travel writing, which is a blend of autobiography and reporting and as such, can be classified as subjective and ideological, rather than objective and literal (Moffat, 2009; Youngs, 2006). This means that the language in the book reflects the author's cultural background. Another textual feature pertinent to this study relates to the departure of Travels in Arabia Deserta from the writing traditions of British travelers to Arabia (Long, 2014). This book shifts from the norms of travel writing in the $19^{\text {th }}$ century, because it is devoid of references to landmark works on Arabia (Long, 2014). In other words, Doughty did not reference earlier travel writings in his book. Furthermore, the book has been a central object of analysis in two areas of research, namely literary criticism (e.g., Kaddal, 1962; McCormick, 1951) and travel writing (e.g., Cocking, 2007; Melman, 2002; Youngs, 2006). However, the book's lexical items in relation to Oriental themes have yet to be investigated. This study seeks to illuminate such lexical choices by applying the frameworks outlined in the following section.

\section{THEORETICAL FRAMEWORKS}

\section{Orientalism}

This study is situated within the conceptual framework of Orientalism as advanced by Said (1978). An outline of the main features thereof clarifies the basis of this study. Said (1978) famously described Orientalism as a "Western style for dominating, restructuring, and having authority over the
Orient" (p. 3), attaching great significance to the impact of discourse produced by the West. In other words, the concept of the Orient is produced through practices of representation put forward by the West. Another characteristic of Orientalism as discourse is the distinction drawn between the West (e.g., Britain) and the Orient (e.g., Arabia) in Orientalist writings. One example of this distinction is the use of dualistic language (e.g., us and them, West and East) (Said, 1978). The concept of the Orient, then, becomes a construct of difference signaling the "Other" rather than a factual representation of Arabia. This difference is measured against the superiority of the West as the representative of the modern and progressive world (Hartley, 2002). Those who come from the progressive world perceive themselves as being "rational, peaceful, liberal, logical, capable of holding real values, without natural suspicion and distrust" (Said, 1978, p. 49), while those in the Orient are labelled with corresponding negative descriptions. Having painted a broad picture of Orientalism, the importance of addressing analytical frameworks capable of capturing this concept as a discourse becomes apparent.

\section{Critical Discourse Analysis}

The suitability of CDA in analyzing Orientalism becomes evident when discussing the principles of this analytical approach. The following discussion is derived from multiple sources (Fairclough, 2015; Machin \& Mayr, 2012; Said, 1978; van Dijk, 2006; Varisco, 2017) to highlight the match between the conceptual framework and analytical approach of this study. A major principle of CDA is that language produces and reflects the ideology that corresponds to the significance of the role of discourse in sustaining Orientalism. Similarly, consistent with the view that Orientalist writings project power in that they construct the Orient, CDA takes the manipulative power of discourse as its point of departure. This means that issues concerning power and dominance attract both. Given these shared similarities, it is argued that Fairclough's (2015) dialectical-relational approach provides a valuable explanatory tool for Oriental discourse. This commonly applied approach highlights three stages in the critical analysis of any discourse, namely description, interpretation, and explanation (Fairclough, 2015). Description is concerned with the linguistic analysis of the text, whereas interpretation and explanation attempt to understand the identified linguistic choices in light of the text consumption production process and wider social practices (e.g., Oriental views). As such, a successful application of this approach necessitates the use of a defined linguistic framework, which is explained in the next section.

\section{The Appraisal Framework}

To ground and validate the linguistic analysis of lexical items, this study applies the Appraisal framework (Martin \& White, 2005; White, 2002a, 2002b, 2006), which can be traced to M.A.K. Halliday's Systemic Functional Linguistics (White, 2015). There are two reasons for situating the linguistic analysis within this framework. One is that the 
Appraisal framework can elucidate Oriental themes, given its concern with investigating evaluative language (i.e., negative/positive language), which is central to the construction of value-laden Oriental themes. In other words, it enables this study to identify Doughty's linguistic choices to construct negative images of Bedouins. The second reason is that both the Appraisal framework and CDA presuppose a link between linguistic choices and certain ideologies. Therefore, the Appraisal framework was chosen for the present study based on its validity as well as its theoretical alignment with CDA principles. Having explained the reasons for employing the Appraisal framework, a brief discussion of its main points becomes essential.

There are three semantic domains under the Appraisal framework that can be used in the analysis of a writer's use of evaluative language (Martin \& White, 2005). However, only one domain, that of attitude, is relevant to the investigation of Oriental themes in Doughty's book. This is because the attitude domain maps the writer's implicit and explicit values, which is helpful in the analysis of embedded Oriental themes. The wide-encompassing concept of attitude deals with expressions of feelings, and is subdivided into the following three types (Martin \& White, 2005): (1) affect, which attends to the emotional reactions of the appraiser (e.g., Sara fascinated me); (2) judgment, which evaluates human behavior by referring to institutionalized notions of right and wrong (e.g., Sara is objective); and (3) appreciation, which revolves around the evaluation of objects and events (e.g., Sara's book is interesting) (Martin \& White, 2005). This suggests that attitude types are identified according to the target of appraisal. Another way to identify the type of attitude is by considering the source of appraisal. For instance, affect deals with the feelings of the appraiser, while judgment and appreciation focus on the qualities of the appraised entity (Thompson, 2014). Also noteworthy in the analysis of attitude is the degree of explicitness. When evaluative meaning is explicitly stated, its negative or positive value is inherent in the lexical item, as in "corrupt, success, beautiful"; thus, it is described as an "inscribed" evaluation. If this evaluative meaning is derived from the general context, rather than carried in a specific lexical element, then it is labeled a "triggered" evaluation (White, 2006). Since attitude is not always inscribed in one word, the unit of analysis for attitude is not limited to single lexical items, but extends to phrases, sentences, and propositions (White, 2002a). Following this categorization of attitude, a linguistic analysis was conducted to unravel the representation of Bedouins by examining lexical choices and the Oriental themes they inscribe or trigger. A more detailed description of the analysis follows.

\section{METHODOLOGY}

Given the qualitative nature of the research questions, this study took multiple steps to cover the targeted aspects thereof. These steps are based on Fairclough's (2015) three-dimensional model described above. For description, the Appraisal framework was used to identify evaluative lexical items, and both Appraisal and Orientalism were applied in the interpretation stage. This was done by re- lating lexical choices to Oriental themes identified in previous studies (Bowen, 2015; Izadi \& Saghaye-Biria, 2007; Loomba, 2015; Volpe, 2014): (1) Oriental inferiority, (2) Oriental barbarity, and (3) Oriental untrustworthiness. Note that both the description and interpretation stages were combined in the text analysis. To interpret the findings of the text analysis, a final step to link the text to power relations governing the production of the text was undertaken. Regarding the scope of data analysis, all described steps were applied to Chapter 9 in Doughty's (1888) Travels in Arabia Deserta, as it centers on the customs and habits of the Bedouins, which is the focus of the study. Although other chapters, such as Chapter 8 and 10, tackled the lives of the Bedouins, the author offered a detailed description of their customs only in the Chapter 9, which is why it was selected for analysis.

On the other hand, a common objection against CDA analysis should be considered, namely the subjectivity of analysis (Fairclough, 2015; Paltridge, 2012). This subjective element cannot be eliminated entirely, but can be reduced by describing the reading position of the analyst (Martin \& White, 2005). In this reading of Doughty's book, the analyst relied on her cultural background to understand the reading of her community. This means that the analyst positioned herself in a community of readers who share the same Arabic culture to avoid an idiosyncratic reading of the text.

\section{TEXT ANALYSIS}

The textual analysis aims to find answers to the two research questions concerning Doughty's use of lexical items and the Oriental themes emerging from such lexical choices. In other words, this section focuses on the description and interpretation stages of Fairclough's (2015) three-dimensional model. The decision to combine description and interpretation in one analysis stage is expected to produce a concise text analysis. Both attitude and Orientalism were utilized as tools to examine Doughty's linguistic choices and understand their evaluative power. Accordingly, the following excerpts from Chapter 9 were analyzed with the help of attitude types (i.e., affect, judgment, and appreciation) and Oriental themes (i.e., inferiority, barbarity, and untrustworthiness) (see Appendix). These excerpts are for illustration purposes only; therefore, they are not exhaustive of all instances of attitude types or Oriental themes.

\section{Oriental Themes}

There is as well that which is displeasing in their homely talk. The mind is distempered by idleness and malice; they will hardly be at pains to remember suddenly, in speech, their next tribesman's name; and with this is their barbarous meddling curiosity, stickling mistrust one of another and beggarly haggling for any trifle, with glosing caresses, (would they obtain a thing, and which are always in guile) impudent promises and petulant importunity. (Doughty, 1888, p. 265).

This excerpt describes what Doughty found to be disagreeable in the behavior of the Bedouins. Note that this is introduced to the reader after a two-page description of 
"the cheerful musing Bedouin talk" (p. 262). While giving equal space to the perceived positives and negatives of the Bedouins' life afforded Doughty a reputation as a reasonably objective travel writer (e.g., Nash, 2011), this manner of presentation does not necessarily exclude the selectivity of Doughty's perception. Indeed, three Oriental themes - inferiority, barbarity, and untrustworthiness - emerge from the author's use of evaluative lexical items in the above excerpt. Several lexical items such as idleness, malice, barbarous, meddling, stickling, beggarly, haggling, guile, impudent, and petulant are used to evaluate the Bedouins' behavior. In attributing idleness and malice to the Bedouins, the author constructs an image of a lazy and sluggish Bedouin who does not only prefer unemployment, but also rejoices in others' suffering. Doughty's negative evaluation of the Bedouins' mental states is in line with the mental inferiority theme sustained in later Orientalist discourses. Even when the Bedouins are curious, their active interest is regarded as a barbarous and meddling behavior, not as a sign of an inquisitive nature. Doughty strongly disapproves of the Bedouins' interest in other people's affairs, and this disapproval is highlighted by his use of the explicitly negative adjective "barbarous," which foregrounds the civility and higher status of the author in relation to his object of description. The difference in social norms concerning inquiring about acquaintances is what made Doughty react negatively and depict the Bedouins in such a negative manner.

The British eye becomes most apparent when describing the cultural phenomenon of haggling (i.e., bargaining), a common practice in Arabia, as beggar-like. The Bedouins' engagement in bargaining is portrayed as "stickling mistrust one of another." This negative interpretation of a typical transaction scenario in any of part of Arabia might be understood considering the lack of such a custom in Doughty's homeland; thus, it is foreign to him. Rather than considering the ability of reaching agreement over price as showing good negotiation skills, it is perceived as a betrayal of the Bedouins' general trickery and deceptiveness. For Doughty, to be a Bedouin means obtaining things through guile and deception. Their deceit is further reflected in their empty promises and demands for favors. This negative assessment of social behavior constructs the Bedouins in Doughty's book as shameless, habitual liars.

Overall, the analysis of Doughty's attitudinal viewpoint in the first excerpt indicates that he relied on the concept of judgment and, specifically, propriety to describe the Bedouins. As such, he assessed their behavior according to the social standards and norms of $19^{\text {th }}$-century Britain. The relativity of social standards escaped Doughty, making the construction of Oriental themes such as inferiority, barbarity, and untrustworthiness possible. The next example arrives at a similar conclusion.

\section{Oriental inferiority}

The herdsmen's tongue is full of infantile raillery and, in sight and hearing of the other sex, of jesting ribaldry: they think it innocent mirth, since it is God that has founded thus our nature. (Doughty, 1888, p. 265).
This part further develops the inferiority theme presented in the preceding example, demonstrating Doughty's consistency in describing the Bedouins. A focus on evaluative items such as infantile, jesting, and innocent highlights the construction of this inferior image. That the Bedouins enjoy and engage in friendly humor at every possible occasion strikes Doughty as odd, leading him to portray such humorous language and behavior as child-like. His view of humor-loving Bedouins is indicated by his use of the adjective "infantile," which negatively evaluates their behavior as characteristic of infants, undermining its appropriateness for adults. Here, parallels are drawn between mature Bedouins and immature children based solely on the former's ability to exploit mockery in different situations. Implicit in this comparison is the inherent inferiority of the Bedouins, whose playfulness contradicts the $19^{\text {th }}$-century British gentlemen's codes of conduct, which valued being reserved and withdrawn in interactions. Understanding Doughty's viewpoint clarifies why he evaluated the raillery and joking exchanges among the Bedouins as "infantile" and not gentlemanly. The use of the adjective "infantile" cannot be explained as an ordinary instance of flowery language, but should be attributed to the author's cultural background in which such exchanges are frowned upon and seen as inappropriate.

This culturally-derived evaluation is also evident in how male Bedouins are pictured in "sight and hearing" of their female counterparts. Male Bedouins begin to act out of control whenever a woman comes into view. Their talk is full of "jesting ribaldry," as they use word play and humorous, vulgar language when discussing women. The scale with which the author measured the appropriateness of the Bedouins' language was based on what was considered socially acceptable flirting in $19^{\text {th }}$-century Britain. The author's use of the third-person pronoun "they" in reporting the belief that profane language is "innocent" play distanced him from this belief shared among the Bedouins.

Thus, Doughty's negative evaluation of the Bedouins' sense of humor was achieved through implicit and explicit means. Instances where lexical items inscribe negative assessment are viewed as explicit evaluation, while in cases of implicit evaluation, a negative attitude is derived from the context. The author used both types of evaluation to attribute the Bedouins' innate disposition to humor to their inferiority. This evaluation is subjective, as one might sketch a positive image of Bedouins by asserting that they can joke with each other without taking offence, which indicates their close relationships. Despite the availability of this positive evaluation, Doughty depicted the interactions of the Bedouins negatively by evaluating them as being more like children than adults.

\section{Oriental untrustworthiness}

Their lie is an easy stratagem and one's most ready defense to mislead his enemy. Nature we see to be herself most full of all guile, and this lying mouth is indulged by the Arabian religion. (Doughty, 1888, p. 242).

This sample further shows how Oriental untrustworthiness is developed in Chapter 9. A frequent characteristic 
ascribed to the Bedouins in this chapter is deceitfulness. Deception is constructed as part of their lives through lexical metaphors, which are exemplified in the portrayal of lies as easy stratagems and "one's most ready defense." Doughty did not explicitly judge the Bedouins as liars, but his comparison of their lies with weapons implies it, as weapons are used in combat for offence or defense. The Bedouins were skillful users of such instruments, as they could easily wield lies to fend for themselves. As such, lying for them is an "easy stratagem" utilized for "ready defense" and protection purposes. In fact, these lies are not only used with the enemy, they are "indulged" in and heavily practiced by the Bedouins. This indulgence in deceitful behavior enables the author to categorize a Bedouin's mouth as a "lying" one. By starting with an implicit judgment and then moving to an explicit one, the author attempted to persuade readers and convince them of the legitimacy of his evaluations. While the previously examined excerpts contain mostly lexical items conveying explicit attitudinal meaning, the last example attempts to show how Doughty implicitly evoked evaluation by leaving the space open to the reader's interpretation.

\section{Oriental barbarity}

Others, having received my medicines, the elves withheld the price; for all that the Beduin can catch of another man's good is his booty. There were some so ungracious ones that they have stolen away the cups in which, with much pains, I had charitably mixed them medicines; poor losses, but that cannot be repaired in the desert. (Doughty, 1888, p. 257).

This part describes the daily struggles of Doughty as a self-proclaimed doctor and his encounters with the Bedouins. The normality, capacity, and propriety of the Bedouins were judged in this part of the chapter. The author judged the normality of the Bedouins, referring to them as "elves," which implied that the Bedouins were devious individuals with impulsive tendencies and not rational human beings capable of self-directed actions. Additionally, the first sentence of this excerpt shows how Doughty negotiated his negative view of Bedouins with the reader. The author first mentioned that he was robbed by "the elves," and then generalized his experience with his observation that "all that the Bedouin can catch of another man's good is his booty." Doughty's claim that the Bedouins were thieves is based on a generalization drawn from one case. Such a generalization is rejected because the case is not characterized by a high degree of exemplariness and might therefore be atypical. Nevertheless, this kind of description might send a message to the reader that all Bedouins are barbarous thieves who should not be trusted. The observation that Bedouins glorify money and plundering can only indicate their barbarity and inhumanity. This contrasts with Doughty's refined and sensible character, who "charitably" offered medical treatment to the ungracious and elf-like Bedouins. The Bedouins' ingratitude shows particularly in their attempts to evade payment and play tricks on Doughty.

Here, the only positive judgment in this excerpt is reserved for the author, which is explicitly inscribed in the adverb "charitably," while the negative judgments are allo- cated to the Bedouins. In this excerpt, the author conveys his negative evaluation of the Bedouins through implicit and explicit linguistic means. Examples of explicit evaluation include the use of the lexical metaphor "the elves" and single lexical items invoking attitudes such as "ungracious" and "charitably." On the other hand, implicit evaluation is triggered by the sentence "for all that the Beduin can catch of another man's good is his booty." The investigation of explicit lexical items such as "charitably" facilitates the process of understanding the implicit evaluative meanings triggered by the surrounding context. The implicit evaluation hints at the author's sense of superiority. This is consistent with Long's (2014) analysis, which reveals that Doughty described the indigenous people of Arabia as "superficial and 'exteriorized' individuals simply incapable of the moral depth and substance of Carlyle's prophet or Doughty/Khalil" (p. 53).

Having used both attitude and Orientalism as investigative and explanatory tools, several points should be outlined. The analysis of the four excerpts indicates that the Arabian Peninsula Bedouins are represented as the Oriental other. This representation was mostly done through explicit rather than implicit ways of formulating positive and negative. The analysis also shows that the attitude type judgment is the most frequently used evaluation in the analyzed excerpts. This type of attitude evaluates human behavior according to social norms, suggesting that Doughty used lexical items carrying explicit judgments based on what was considered socially acceptable in $19^{\text {th }}$-century Britain. To explain why Doughty represented Bedouins in this way, the next section examines the power relations (i.e., British and Arabian relations) that gave rise to the discourse of Travels in Arabia Deserta.

\section{DISCUSSION}

While the previous section attempted to identify Doughty's use of lexical items and relate them to prevalent Oriental themes in the literature, this part aims to fit the discourse of Travels in Arabia Deserta into a bigger picture. In so doing, this study can grasp its hidden ideology by examining power relations. This final stage of CDA aims to identify the power exerted through the text over the real world (Fairclough, 2015). That is, Doughty's representation of the Bedouins in his book has constructed and sustained a view of Bedouins that may not have reflected them in reality, yet affected their lives and those associated with them. The discursive power of Doughty's representation, in the sense that it shapes the social subject of the Bedouins, in a certain way hints at a hidden ideology that enabled such a discursive representation.

\section{Hidden Ideology}

One of the main hidden ideologies embedded in Doughty's representation of Bedouins is the sense of Western superiority. The detection of this hidden ideology was possible through the Appraisal framework-based linguistic analysis. The use of this framework illustrates that the concept of superiority governs the evaluative language found in Doughty's book. Dismantling the author's use of evaluative lexical 
items reveals that culturally-based attitudes (i.e., judgment) are the most common. Given that the Appraisal framework maintains that judgments are evaluations based on "ethics/ morality and other systems of conventionalized or institutionalized norms" (White, 2015), then it is safe to say that Doughty relied on a specific system in measuring the behavior of Bedouins and by extension, their culture. This system is grounded in $19^{\text {th }}$-century British notions of civility and morality. By holding British ideals as a reference, it is not surprising that Doughty viewed Bedouins who embraced different ideals as inferior, barbarous, and untrustworthy. The imperial dominance of Britain in the $19^{\text {th }}$ century and its notions of civilization informed Doughty's evaluative language and shaped the discourse of his book.

\section{Discourse of Orientalism}

Returning to the earlier point raised in the introduction about the need to view Orientalism from a historical perspective (Burke \& Prochaska, 2008; Dabashi, 2009; Varisco, 2017), this analysis of a key founding text addressing the people of Arabia (Cocking, 2007) can elucidate the nature of Orientalism as a discourse. Rather than being confined to works adopting a colonial framework, this study supports the idea that the label "discourse of Orientalism" (Said, 1978) encompasses even seemingly neutral descriptions and observations of the people of Arabia. Indeed, this interpretation explains how even in the lack of colonial interests, Doughty's work still shares similarities with other typical discourses framed within Orientalism. This similarity is seen in the depiction of a traveler with a colonial mindset, namely TE Lawrence's characterization of the natives of Arabia as childish (Volpe, 2014), which parallels the Oriental inferiority theme revealed in this study. The resemblance of discursive representations of Bedouins in Doughty's and TE Lawrence's books is interesting. It shows that even when a Western traveler does not pay much regard to the colonial interests of his country in the region of Arabia, he is bound to represent them from an Orientalist perspective as the different other. This explains how representations of Bedouins as the Oriental other are constructed by Doughty who has no colonial interests (Youngs, 2006). All of the identified representations in Doughty's book are still invoked in news media and extended to characterize all Arabs regardless of their geographical location (e.g., Alghamdi, 2015; Ventura, 2017). As such early representations of Bedouins are sustained through current media discourses, one can conclude that the representation of people of Arabia is a product of an accumulated body of work over a long period and not of one text (Mcinturff, 2003). This interconnectedness of discourses shapes and sustains Orientalism. Further studies need to investigate the emergence and development of Oriental themes in the discourse of travel writing on Arabia.

\section{CONCLUSION}

CDA studies on the discourse of Orientalism have primarily focused on analyzing fiction books and media texts produced in the $20^{\text {th }}$ or $21^{\text {st }}$ centuries. This study, however, explored a $19^{\text {th }}$-century travel writing book by Charles Doughty, entitled Travels in Arabia Deserta. For the purpose of tracing early representations of the Arabian Peninsula Arabs, a chapter from Doughty's (1888) book dealing with the customs and character of Bedouins was analyzed. This analysis was conducted utilizing the Appraisal framework as a tool of analysis for the author' lexical choices and CDA as an explanatory framework. Consistent with the literature, three Oriental themes emerged in this study: (1) Oriental inferiority, (2) Oriental barbarity, and (3) Oriental untrustworthiness. This suggests that Doughty represented Bedouins as mentally inferior to Western people, as well as barbarous and deceptive. These cognitive and behavioral descriptions are still invoked in news media and extended to characterize all Arabs regardless of their geographical location (e.g., Alghamdi, 2015; Ventura, 2017). As such, the examination of the Oriental themes in Travels in Arabia Deserta highlighted two processes of the discourse of Orientalism. One is the underlying superiority of the West, and the other is the interdependence of texts describing the natives of the land of Arabia. More research should be conducted on the non-fiction western writings of the $19^{\text {th }}$ century if Oriental discourse is to be understood and ultimately challenged.

\section{ACKNOWLEDGMENT}

I am grateful to Dr. May Abumaliha for her extensive and insightful comments on earlier drafts of this study. I would like to thank Dr. Salem Alshimemeri for reading each word of the final draft and providing useful feedback. I would also like to thank the anonymous reviewers for their valuable comments and suggestions. The author thanks the Deanship of Scientific Research and RSSU at King Saud University for their technical support.

\section{REFERENCES}

Al-Malik, A. M. T. (2014). The image of the Other: Representations of East-West encounters in Anglo-American and Arabic novels (1991-2001). (Doctoral thesis). University of Exeter, Exeter, UK.

Alghamdi, E. A. (2015). The representation of Islam in Western media: The coverage of Norway terrorist attacks. International Journal of Applied Linguistics and English Literature, 4(3), 198-204. http://dx.doi.org/10.7575/ aiac.ijalel.v.4n.3p.198.

Bowen, K. (2015). Representing Persia: A discourse analysis of the American print media's coverage of Iran. (Master's thesis). London School of Economics and Political Science, London.

Burke, E., \& Prochaska, D. (Eds.). (2008). Genealogies of orientalism: History, theory, politics. Lincoln, USA: University of Nebraska Press.

Cocking, B. (2007). Writing the end: Wilfred Thesiger, Freya Stark and the 'Arabist tradition.' Journeys: The International Journal of Travel and Travel Writing, 8(1-2), 57-76. http://dx.doi.org/10.3167/jys.2007.08010204.

Dabashi, H. (2009). Post-Orientalism: Knowledge and power in time of terror. Austin, USA: Transaction Publishers. 
Doughty, C. M. (1888). Travels in Arabia Deserta (Vol. 1). Cambridge: Cambridge University Press.

Encyclopædia Britannica (2016). Charles Montagu Doughty. Retrieved January 1, 2017, from https:/www.britannica.com/biography/Charles-Montagu-Doughty.

Faimau, G. (2013). Socio-cultural construction of recognition: The discursive representation of Islam and Muslims in the British Christian news media. Newcastle upon Tyne, UK: Cambridge Scholars Publishing.

Fairclough, N. (2015). Language and power ( $3^{\text {rd }}$ ed.). UK: Routledge.

Hartley, J. (2002). Communication, cultural and media studies: The key concepts ( $3^{\text {rd }}$ ed.). New York: Routledge, Taylor \& Francis Group.

Izadi, F., \& Saghaye-Biria, H. (2007). A discourse analysis of elite American newspaper editorials: The case of Iran's nuclear program. Journal of Communication Inquiry, 31(2), 140-165. https://doi.org/10.1177/0196859906298073.

Jarmakani, A. (2008). Imagining Arab womanhood: The cultural mythology of veils, harems, and belly dancers in the US. US: Palgrave Macmillan.

Kaddal, M. A. M. (1962). Charles Montague Doughty: His life and works. (Doctoral thesis). University of Glasgow, Glasgow.

Long, A. C. (2014). Reading Arabia: British Orientalism in the age of mass publication, 1880-1930. Syracuse, NY: Syracuse University Press.

Loomba, A. (2015). Colonialism/Postcolonialism ( $3^{\text {rd }}$ ed.). London: Routledge.

Macfie, A. L. (2009). Orientalism: A reader. Edinburgh: Edinburgh University Press.

Machin, D., \& Mayr, A. (2012). How to do Critical Discourse Analysis: A multimodal introduction. Los Angeles: Sage.

MacKenzie, J. M. (1995). Orientalism: History, theory and the arts. Manchester: Manchester University Press.

Martin, J. R., \& White, P. R. R. (2005). The language of evaluation: Appraisal in English. London: Palgrave Macmillan.

McCormick, A. M. (1951). The origin and development of the style of Charles M. Doughty's Travels in Arabia Deserta. (Doctoral thesis). University of London, London.

Mcinturff, K. (2003). Emancipation, experience, and anti-foundationalism. In I. E. Boer (Ed.), After Orientalism: critical entanglements productive looks (pp. 219238). Amsterdam: Rodopi.

Melman, B. (2002). The Middle East/Arabia: "The cradle of Islam.” In P. Hulme \& T. Youngs (Eds.), The Cambridge companion to travel writing (pp. 105-121). Cambridge: Cambridge University Press.
Moffat, R. H. (2009). Perspectives on Africa in travel writing: Representations of Ethiopia, Kenya, Republic of Congo and South Africa, 1930-2000 (Doctoral thesis). University of Glasgow, Glasgow.

Nash, G. (2011). Travellers to the Middle East from Burckhardt to Thesiger: An anthology. London: Anthem.

Paltridge, B. (2012). Discourse analysis: An introduction ( $2^{\text {nd }}$ ed.). UK: Bloomsbury Publishing.

Poorebrahim, F., \& Reza Zarei, G. (2013). How is Islam portrayed in Western media? A critical discourse analysis perspective. International Journal of Foreign Language Teaching and Research, 1(2), 45-62.

Said, E. W. (1978). Orientalism. New York: Pantheon Books. Sullivan, A. T. (1969). The obstinate Mr. Doughty. AramcoWorld, 20(4), 2-5.

Thompson, G. (2014). Introducing functional grammar ( $3^{\text {rd }}$ ed.). New York: Routledge.

van Dijk, T. A. (2006). Ideology and discourse analysis. Journal of Political Ideologies, 11(2), 115-140. https:// doi.org/10.1080/13569310600687908.

Varisco, D. M. (2017). Reading Orientalism: Said and the unsaid. Seattle: University of Washington Press.

Ventura, L. (2017). The "Arab Spring" and orientalist stereotypes: The role of orientalism in the narration of the revolts in the Arab world. Interventions, 19(2), 282-297. https://doi.org/10.1080/1369801X.2016.1231587.

Volpe, A. (2014). "Going native” In the British Empire; David Livingstone and T.E. Lawrence revisited. (Master's thesis). CUNY City College, New York.

White, P. R. R. (2002a). Appraisal - the language of evaluation and intersubjective stance. Retrieved December 12, 2017, from www.grammatics.com/appraisal.

White, P. R. R. (2002b). Appraisal - the language of evaluation and stance. In J. Verschueren, J. Östman, J. Blommaert, \& C. Bulcaen (Eds.), The handbook of pragmatics (pp. 1-27). Amsterdam: John Benjamins.

White, P. R. R. (2006). Evaluative semantics and ideological positioning in journalistic discourse - a new framework for analysis. In I. Lassen, J. Strunck, \& T. Vestergaard (Eds.), Mediating ideology in text and image: Ten critical studies (pp. 37-68). Amsterdam: John Benjamins Publishing Company.

White, P. R. R. (2015). Appraisal theory. In K. Tracy (Ed.), International encyclopedia of language and social interaction (pp. 14-36). Hoboken, U.S.A: Wiley-Blackwell.

Youngs, T. (2006). Introduction: Filling the blank spaces. In T. Youngs (Ed.), Travel writing in the nineteenth century: filling the blank spaces (pp. 1-18). London: Anthem Press. 


\section{APPENDIX}

\begin{tabular}{|c|c|c|}
\hline Linguistic choices & Attitude & Oriental themes \\
\hline \multicolumn{3}{|c|}{ Excerpt A } \\
\hline The mind is distempered by idleness and malice & Judgment & Inferiority \\
\hline Barbarous meddling curiosity & Judgment & Barbarity \\
\hline Stickling mistrust one of another & Judgment & Untrustworthiness \\
\hline Beggarly haggling for any trifle & Judgment & Untrustworthiness \\
\hline Are always in guile & Judgment & Untrustworthiness \\
\hline Impudent promises & Judgment & Untrustworthiness \\
\hline Petulant importunit & Judgment & Untrustworthiness \\
\hline \multicolumn{3}{|c|}{ Excerpt B } \\
\hline Infantile raillery & Appreciation & Inferiority \\
\hline Jesting ribaldry & Appreciation & Inferiority \\
\hline They think it innocent mirth & Judgment & Inferiority \\
\hline \multicolumn{3}{|c|}{ Excerpt C } \\
\hline Their lie is an easy stratagem & Appreciation & Untrustworthiness \\
\hline one's most ready defense & Appreciation & Untrustworthiness \\
\hline This lying mouth is indulged & Judgment & Untrustworthiness \\
\hline \multicolumn{3}{|c|}{ Excerpt D } \\
\hline The elves & Judgment & Barbarity \\
\hline For all that the Beduin can catch of another man's good is his booty & Judgment & Untrustworthiness \\
\hline Ungracious ones & Judgment & Untrustworthiness \\
\hline I had charitably mixed them medicines & Judgment & - \\
\hline
\end{tabular}

